\title{
Globalization and educational change: bringing about the reshaping and re- norming of practice
}

\author{
Lawrence Angus* \\ University of Ballarat, Australia
}

The tendency in education writing on globalization has been to examine the congruence of educational policies in western societies and the international effects of global governance of education by powerful transnational institutions such as the Organization for Economic Cooperation and Development and the European Union. The authors tend to identify massive changes in approaches to educational governance, including the establishment of a broadly common policy and management agenda that is characterized by 'new managerialism', devolution, and rigid accountability structures, entrepreneurialism, and school effectiveness, that have been imposed largely as a result of globalization. These measures are often seen as being directly related to the 'hollowing out' of the state, and the emergence of neo-liberalism as the informing ideology of both international capitalism and residual nation-states. There are few studies, however, of the dynamics of educational life and micro-political activities that enable or challenge or bring about the kinds of educational reshaping and renorming that are typically associated with globalization. This study attempts to analyse such micro-shaping, which, through reporting an ethnographic study in a site of educational practice, examines how school managers and teachers dealt with government policy intervention and, in the process, both willingly and unwillingly implemented significant educational change.

\section{Introduction}

With few exceptions, education writers ascribe to 'strong' globalization theories (Hirst \& Thompson, 1996; Wilding, 1997; Stryker, 1998) that generally emphasize the dominance of the global economy over national and international politics. There is a tendency to present globalization as economic determinism, homogeneous in its effects throughout the planet. Such globalization theory tends to be essentialist and

\footnotetext{
*Head, School of Education, University of Ballarat, PO Box 663, Ballarat, Vic 3353, Australia. Email: 1.angus@ballarat.edu.au
} 
reductionist, as it implies a totalizing structure that imposes its will without much if any consideration of agency, local politics, or resistance. As Wilding (1997, p. 411) summarizes this argument:

The term [globalization] is most commonly used to describe certain trends in economic, political, social, and cultural development. The term is also used, however, to explain such trends - they are as they are, the argument runs, because of this force we call globalization.

Such conceptions of globalization pay little attention to ways in which global agendas might be asserted or resisted and played out in particular regions or sites, rather than simply being received and implemented. Globalization is typically presented as an external phenomenon that results, at the school level, in such neo-liberal features as managerialism, competition, and market arrangements. The complex shifts between, say, 'welfarism' and 'new managerialism' (Gewirtz \& Ball, 2000) that may come about at the school level may be closely described and explored in terms of 'discursive shifts' (Gewirtz \& Ball, 2000), but rarely explained.

There is often a sense of linear effects of new managerialism on principal and teacher practice and subjectivity. Concepts such as 'policy borrowing' (Dale, 1999), 'migrating' policy metaphors (Ball, 1997; Edwards et al., 1999), and 'travelling policies' (Jones, 2001) have often been used to describe and explain the emergence of apparently common education policies across a range of countries. These include policies of accountability, market organization, managerialism, the reconstruction of teacher professional identities, school self-management, school inspection, and school effectiveness. However, because so many writers reduce explanations to strong, totalizing versions of globalization theory, these things are described more or less as if they simply 'are'; as if they are current features of the social and educational landscape that exist in the globalization era and which need to be mapped and described rather than explained in context. Their meanings are rarely analysed in sites of educational practice. Globalization and its accompanying change are typically presented as irresistible forces (Edwards et al., 1999; Inglis, 2000). For example, many discussions of education policy in England seem to compare the situation now (of globalization) with a past (pre-globalization) when education policy and values and entrenched thinking were localized, 'welfarist' (Gewirtz \& Ball, 2000) and characterized by a sense of educational 'partnership' (Lawn, 2001). Such values and norms are often regarded as part of an historical framing of educational politics over which government benignly presided in the UK from $~ 1950$ until the period of Thatcher intervention and assertion of control in the 1980s.

Lawn (2001), for instance, is among those who refer to the 'powerful discourse of partnership' that 'gave meaning to teaching' during the post-war period (p. 175). $\mathrm{He}$ elaborates: 'Teachers were professionals, fostered by the state, partners in the deliberation of policy, able to influence the direction and control of the system' (p. 175). However, surely, despite the pluralist rhetoric of partnership, things were never as neat and rosy as that, or else what was the point of all the critical sociological work in education during the 1960s, 1970s and 1980s (e.g. Whitty, 1977, 1985)? Lawn's view seems too romantic and golden ageist. Any sense of partnership that might have 
existed by, say, around the late 1970s, was not just the result of the gift of government, but the outcome of contested educational politics that were asserted and fought over by teachers and their unions (Bessant \& Spaull, 1976). To say, as Lawn does, that the post-war 'policy' of acknowledgement of teachers as 'heroes of reconstruction, as pedagogic innovators, as carers, as partners of and within the public' is what 'gave meaning to teaching' (p. 175) may be an over-statement. Indeed, the reverse could be argued - that the political assertion by teachers of educational priorities and professional culture called forth the notion of partnership and forced the recognition by government and society that teachers were significant players in educational policy debates.

This latter scenario certainly describes the situation in post-war Australia (Bessant \& Spaull, 1976), and certainly in the State of Victoria in which the 'partnership' ideal had been briefly legitimated (to an extent that was greater than in any other Australian State) from the late-1970s to the mid-1980s. Then, during the 1990s, it was extinguished in policy terms within a blitzkrieg of hostile policy intervention in education by an avowedly neo-liberal State government that was the most interventionist and reformist in Australia.

Lawn's (2001) paper implies that educational and national, and even global, cultures can be determined by powerful policy networks that have significant cultural effects and which, among other things, 'are "producing" the new European educational space' (p. 178). The Brussels clique could be perhaps described as being 'important' in influencing cultural and educational 'possibilities', and even as significant 'designers' in the complex process of shaping education and culture, and certainly as 'legitimizers' (p. 178) of asserted educational policies and cultural norms, but probably not as 'producers' or causers of them. The powerful networking that is going on is, admittedly, an important example of political and cultural work being done in education. However, again, something like the reverse of Lawn's scenario could be argued - that the Brussels bureaucrats and networked policy actors may be responding to broader power and politics (for example, the historically rampant assertion of capital) as much as initiating or 'producing' change. I am concerned that some education writers make educational and cultural change seem the mysterious work of networks and 'clubs' (which seems remote and magical and irreversible) rather than the hard graft of power and politics in which we are all implicated.

Such distal accounts of change in education often rely on generalized discourses of globalization to explain the self-disciplining effects of such 'new neo-liberal technologies of institutional control' (Beck, 1999) as new managerialism. For example, in critiquing 'school effectiveness', Morley and Rassool (2000, p. 169) state as given that 'neo-liberal policy meanings have redefined not only the educational process but also teachers' consciousness as workers'. Their approach to the analysis of new managerialism assumes the successful realization of the outcomes that are envisaged in putative 'regimes of truth' that are seemingly imposed on schools and within which people are captured without demur. Or, as Bacchi (2000, p. 52) puts it: 'those who are deemed to "hold" power are portrayed as the ones making the discourse, whereas those who are seen as lacking power are described as constituted in the discourse'. So, although 
complementary discourses of globalization and managerialism have been asserted with great vigour within various literatures, government policy, and practitioner expectations, such discourse is unlikely ever to amount to a totalized 'regime of truth' in the dynamic world of complex humans who, to varying extents, share and contest overlapping multi-cultures, values, and aspirations, and complex politics of everyday life in everyday contexts like schools.

A major exception to the 'globalization explains all' trend is Dale $(1999,2000)$. When it comes to seemingly common global education policies, Dale $(1999,2000)$ emphasizes the importance of investigating how and why a particular meaning system may have come to appear dominant in particular places. He insists that the effects of assertive capitalism on education, exerted either directly or indirectly through the impact of globalization on states, occur 'through mechanisms that can be specified and traced' (Dale, 2000, p. 441, my emphasis). Following Dale, this paper argues that, at both the micro and macro levels, educational change is concerned with the negotiation and contestation of educational meaning and educational politics.

\section{Methodology}

I endeavour to illustrate processes in which change is brought about in a research site, in which meaning is mediated in institutional frameworks, both organizational and social, and is the result of contested social practices in arenas of unequal power relations. I argue that, although contemporary discourses of globalization and managerialism have been asserted as virtually 'regimes of truth' within various literatures, any educational change, even within the current era of globalization, must be accomplished in the dynamic world of complex human agents. To varying extents, we all share and contest overlapping multi-cultures, values and aspirations, and the complex politics of everyday life.

The ethnographic data reported in the paper indicate that organization members have the capacity to influence organizational norms, practices, and structure, while also simultaneously both adapting to and influencing strongly institutionalized professional expectations within organizations. Ethnographic analysis of such processes and discourses, through which social relations and identities are constituted, may shed a little light on how management and organizational change gets 'accomplished' in schools. The approach to gathering data was to observe as much as we ${ }^{1}$ could at 'Grandridge Secondary College' during a period of 9 months in 1995, and to speak to people there as often as we could. We interviewed 17 people on tape, some on many occasions, and had numerous other conversations. The interviews took place in offices, vacant schoolrooms or homes and were tape-recorded. We spoke to people informally before and after meetings, in staffrooms, in the yard, stairwells, and corridors. We conducted taped interviews first with several individuals in key positions within the school and, at the end of each, asked these interviewees to nominate other people with whom they thought we should talk in order to gain a diversity of views and opinions. We made a list of names most often mentioned and went as far down the list as we could in the time available. Many on the list did not 
have formal interviews but did take part in conversations. Interviews were transcribed and interviewees checked the transcripts for fairness, relevance, and accuracy. We then drew on the transcripts and observation and conversation notes. In this paper, as in our major report of the study (Angus \& Brown, 1997), pseudonyms are used for the school and for participants. No real names are used except for very public figures.

The purpose of this paper is to revisit the original case study in an attempt, retrospectively, to trace the micro-mechanisms (Dale, 2000) through which educational change, that was largely consistent with apparent globalizing educational agendas, was both willingly and unwillingly implemented.

\section{Grandridge Secondary College}

Grandridge Secondary College is in many respects the result of the assertion of an educational discourse that affected teacher professionalism and educational thinking in the decades of the 1960s, 1970s, and 1980s. Of course, such discourses, and the educational practices that embodied them, were differentially institutionalized (and then only provisionally) in different educational organizations. By the end of the 1980s, despite periodic conflicts between management and teachers, staff at Grandridge had been working for more than two decades to institutionalize a general set of progressive educational practices and agendas that many teacher activists had been asserting in Victoria and Australia since the 1960s. In fact, Grandridge had by then become widely recognized among educators as a leading school not just in contributing to the development of progressive and socially-just education, but also, through the commitment, innovation and sheer hard work of its staff, in helping to make progressive education respectable and broadly legitimate. Among staff, there was a widely felt sense of commitment to improving the lot of the 'western suburbs' (a term used to describe a large region of Melbourne characterized by low SES), an emphasis on student centred pedagogy, a belief that curriculum reform could contribute to social as well as educational reform, and a belief that the education profession, including teacher unions, needed to be active in policy debates. Grandridge teachers tended to see themselves as being at the forefront of educational thinking and educational activism. They were committed to making Grandridge a great school, but their motivation was broader than that: it was to educational ideals and the progressive educational movement that had gradually taken hold of a large part of the teaching profession.

In Victoria, a measure of the contribution of activist educators like those at Grandridge to the policy process is that, in the early- to mid-1980s, teachers, through their unions, had become regarded as legitimate participants with government in educational innovation and change. Such 'partnership', as I have indicated, did not come easily. It was an outcome of a period of contestation throughout the 1960s and 1970 s in which teachers, teacher unions, and educational organizations like Grandridge Secondary College, took the lead in the assertion of their professional status as a way of contesting managerial prerogatives that took the form of bureaucratic regulations and control of their work. Before that, education departments had tended to simply order teachers to do as they were told (Bessant \& Spaull, 1976). 
The school Jack Regan took over as principal in 1989 boasted a very strong union branch. Indeed, its perceived identity as a strong union school had become self-maintaining, as many teachers found the prospect of working in such an environment attractive. In the 1980 s, membership of the branch was $100 \%$ of staff. Jack tends to attribute Grandridge's success during that time to the efforts of key individuals whom he regards as catalysts and curriculum leaders. He is able to list a dozen such people in key curriculum areas. One of these says of Jack:

He came to a school which was very dwindling in numbers and struggling. And a lot of talented staff here were involved in improving the sorts of programmes that the school could offer and widening the types of people that the school would appeal to, to come here. And over several years a really brilliant job was done by all.

The election of the Kennett government in late 1992 signalled the end of any shaky partnership between teachers and government. Before it was elected, members of the Kennett-led Coalition (Liberal and National ${ }^{2}$ ) parties emphasized that the new Government would introduce fundamental changes in education and the public sector generally. This point had been made perfectly clear by the leader of the Victorian Liberal Party, when, in an address to business leaders, he stated unequivocally prior to the 1992 election that:

Left wing advocates of progressive education have captured the curriculum with the aim of using it to restructure society according to their socialist ideals ... In contrast, the Coalition acknowledges that education must promote the common beliefs, values and knowledge on which our society is based (quoted in Gaff ,1999, p. 116).

As the October 1992 Victorian election grew nearer the likelihood of a change of government grew greater. Teachers were expecting the worst. There was no secret that education would be dealt with harshly. The policy introduced by the new government for reforming school education had the evocative title of 'Schools of the Future' (SotF). Every government school in the State had become a so-called 'School of the Future' by the government's third year. The policy was intended to curtail the 'social engineering' influence of 'radical' teachers and teacher unions, and to return the control of schools to communities. 'Quality' education was to be achieved by the adoption of 'world's best practice' in the management of schools. In this hostile education policy environment, and in the midst of an immediate round of school closures and a wave of teacher redundancies ( 55 schools were closed in 3 months and $17 \%$ of teachers were removed from the system over 3 years), many Grandridge staff looked to their principal, Jack Regan, to provide some direction.

The Schools of the Future Information Kit (Victoria, DSE, 1993, p. 3) states that the 'aim of Schools of the Future is to improve the quality of education for students by moving to our schools the responsibility to make decisions, set priorities, and control resources'. There was little if any reference to educational processes, pedagogy, teaching or learning styles, or relations among students and teachers. Terms such as marketing, accountability, outcomes, efficiency, appraisal, and competitiveness, however, were used freely in the policy documents and supporting materials. Improved educational outcomes and efficiency would be achieved, it was emphasized, 
by establishing 'an accountability framework' which would include, as its most crucial element, the 'School Charter'. This was referred to as the 'business plan' for the school. The Charter would set the benchmarks against which the school was to be judged by clients and by the system. In fact, the charter was regarded under the policy as a 'contract' between the school and both the local community and the government.

Appointed as principal of Grandridge Secondary College in 1989, Jack had previously relied on his powers of persuasion and his reputation among the staff as a savvy player of the Department games in order to influence staff opinion. He again employed this style in bringing the staff to accept his recommendation, as soon as the Kennett government had been elected and had introduced its flagship Schools of the Future policy, to become a pilot school in the programme. For at least two reasons, looking back, this episode, and particularly the writing of the first School Charter as required under Schools of the Future policy, seems to have been a critical incident in reshaping the school's values and practices. First, it enabled an airing of alternative value positions that resulted in the first major step towards consolidating 'new' business-like values in the school culture. Secondly, although the School Charter was written in terms that many staff intended as defensive of the school's established educational values and culture, it was nonetheless the first clear example of group compromise on previously cherished positions. These points require some discussion.

\section{Becoming a pilot School of the Future: the school charter}

Jack was the central player in the decision process. He was remarkably insistent that Grandridge Secondary College join the pilot SotF programme. The change of government did not alter his basic pragmatic belief that: 'It is better to be inside the tent pissing out than outside the tent pissing in'. This was the theme of a strongly argued memo he sent to all staff prior to a forum at which the decision whether Grandridge would enter the pilot was to be made:

\section{For the past 7 years a system of winners and losers has been operating}

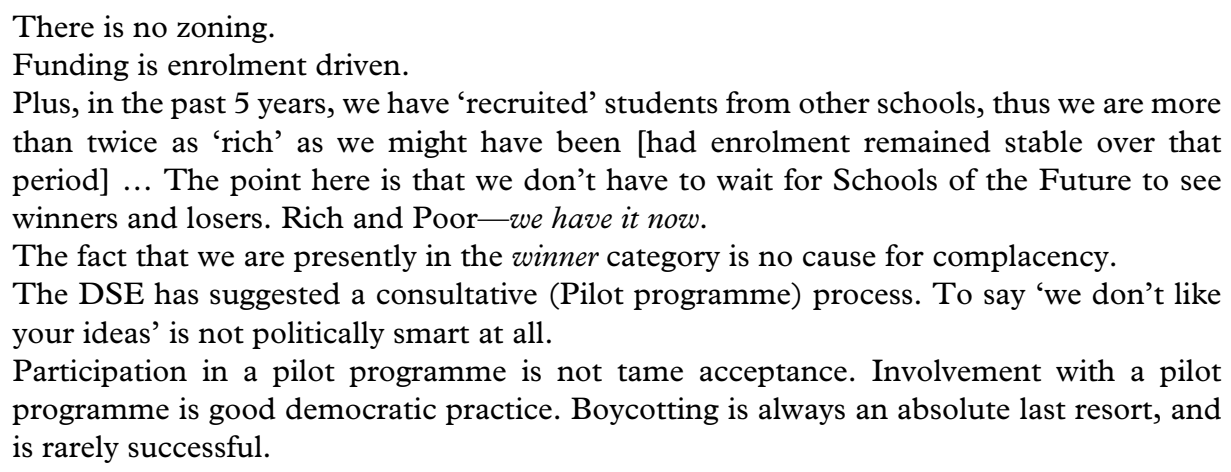

Jack had a long record as a consultative, union-friendly principal and was trusted by staff. Because of his persuasiveness, he quickly secured general acceptance of the 
view that joining the Schools of the Future programme was the pragmatic thing to do. He was able to highlight important continuities within the foreshadowed changes, no matter how drastic, that might occur under the new government. Grandridge Secondary College could, and would, he asserted, remain a player in education debate and make the policies 'less bad'. Jack was advocating strategic compliance. For many staff, the message that they could work to shape the policy from within was a winner. Jack had sold this message heavily and lobbied very hard prior to the forum, but, as one of his critics put it, 'the vote wasn't even close'. Even one who was ambivalent about Jack's argument was able to conclude: 'Jack's built up a lot of points. He'll be forgiven for some mistakes'.

The next stage was to write the School Charter. Again, Jack took the lead. According to one teacher:

\begin{abstract}
We went into the meeting and Jack had the charter written out and he said 'we're going to have percentage increases in this, and percentage increases in that, and percentage increases in the next', and then Alfie just said, 'Well, it really sounds like Stalin doesn't it? You know, its a 5-year plan, and really what's going to happen is our production quotas are going to be made in order to be able to fit the model'.
\end{abstract}

I cannot emphasize too strongly that the central point about the Charter was that it would be the school's business plan. There can be no doubt that the Charter was produced (at Grandridge and other schools) in an educational policy environment that was heavily coercive. As I have emphasized, the incoming conservative government had made it very plain long before it was elected that schools would be in for a major shakeup.

In keeping with Jack's message of practicing strategic compliance, yet recognizing the seachange that the election of the Kennett government symbolized, a number of staff saw the writing of the Charter as requiring a balancing act between 'giving the government what it wants to hear' and in subtle ways affirming the values that had been asserted at Grandridge over a period of more that two decades. Even the strongest critics of the new directions that were explicit in SotF policy accepted that the school had to present itself to its external public, and to government, as entrepreneurial, customer-oriented, businesslike, and outcomes-focussed. Terms like these were already becoming internally legitimized and, as time went on, became increasingly normalized. The process and conclusion of the Charter discussion were, therefore, a critical chapter in the continuing process of legitimate naming, in which the 'seeable and sayable' (Oakes et al., 1998, p. 270) were unintentionally restricted through use of the tactic of strategic public compliance. Then, through the process of public documentation, and next through ongoing internal review of the newly stated priorities, and finally through a continuing concern about meeting the resultant performance targets, the discourse was increasingly consolidated around market and business concepts. Meanwhile, the previously asserted educational and, particularly, social justice notions were becoming less central, more dissonant and began to lose their sacred status in the prevailing professional discourse.

Of particular note here was the unemotional discussion about whether the overall slogan for the School Charter (the theme that would pervade the document) should 
refer to the school's 'performance orientation' or to its 'social justice values'. Eventually, after clinical discussion of what would 'sell' in the community and what the government would tolerate, the majority of staff opted for the 'performance orientation' theme to best represent what the school was about. This decision, in which Jack was again instrumental, prompted one teacher, who was bitterly disappointed at the reluctance of staff to affirm in the Charter what she had thought was the guiding principle of the school, to doubt the extent to which some staff at Grandridge had ever been committed to values of social justice: 'It suits them not to have to pretend any more. It very much suits the school to not have to pretend any more'.

This comment implies that the social justice debate was an old debate, and that there had long been different sides. It also indicates the level of disappointment and disillusionment of this teacher, who now found herself questioning the extent to which previous commitments had been sincere. There is a disturbing rhetoric and reality distinction here that may have been of long standing.

In retrospect, it seems that by agreeing to locate themselves 'inside the tent', and by agreeing to take on board the market and business orientations of SotF policy for purposes of public legitimacy, members of staff had, at least to some extent, 'bought in' to aspects of the change and the new norms that it represented even while adopting a defensive position. Although not welcoming or necessarily accepting the change, they were recognizing it as a force that had to be reckoned with. They were meeting it, and making preparation to deal with it. In keeping with Jack's urging, they were beginning to anticipate and read the changes, and to respond to the new priorities by being 'seen to be doing what the government wants' - but they were 'doing' nonetheless. So, regardless of how it started out, the emphasis on business priorities as a form of defensive or rhetorical strategic compliance soon resulted in staff engagement in pursuing the plans and priorities, particularly as it became perceived as increasingly important that the school attract students and legitimate itself to its external market and the increasingly important 'third parties' (Offe, 1996) of business, public opinion, and government.

\section{School Council ${ }^{3}$ and management}

As persuasive and trustworthy as Jack appeared in the micropolitical context of Grandridge Secondary College, it soon became obvious that staff did not want him to be totally unchallenged. The election of staff representatives to the new School Council, soon after the School Charter had been drawn up, provided an interesting window on staff thinking. Three staff members ran for two vacant positions. Two had been outspoken opponents of the Schools of the Future policy at the forum discussed above. The other was a strong supporter of the principal (soon to be elevated by Jack to the position of Acting Assistant Principal). The teacher who had spoken out most strongly against the school's involvement in the Schools of the Future pilot scheme at the staff forum attracted by far the highest vote. Jack's supporter attracted the lowest and was eliminated from the running. 
However, if staff had expected that there would be vigorous debate at School Council of policy positions, including Ministry directives, they were soon disappointed. School Council powers had been increased substantially under SotF policy, but policy debate and discussion of government regulations were excluded at meetings in order to facilitate the 'business' of the Council in time-efficient ways. The view of most (but by no means all) Council members was that its main role was to provide good, effective management of the school, and to faithfully implement the School Charter. The Council President, a local professional and parent of a child at the school, repeatedly put this view during meetings as 'simply common sense'. $\mathrm{He}$ actively discouraged the use of the School Council by teachers as a forum for contestation of government views or the actions of school management. His habit of referring to the School Council as 'the Board' is indicative of his no-nonsense orientation. He streamlined procedures by ruling that all correspondence, including Ministry correspondence, would be tabled at Council but not discussed, and, when he deemed necessary, by guillotining debate. According to the president: 'Well, what are these teachers on the council for? They're only pushing a particular barrow and it's boring to everybody'.

One matter that the 'barrow-pushing' teachers on School Council would have liked to push further was Jack's use of his enhanced autonomy to create two new management positions. In particular, the designation of one of them as 'Operations' was interpreted by some teachers as signalling a shift in what was officially valued within the school. At Grandridge, the quality of curriculum had long been regarded as central to the school's strength. This is what Jack and numerous teachers claimed had previously made Grandridge distinctive. Many teachers interpreted the designation of an Assistant Principal position as 'operations' as signalling a message about the type of teacher contributions that would be recognized and rewarded under the new regime. As Steve, one of the teachers elected to the School Council, put it:

It's the 'bean counters' largely who have been the ones who have been promoted into the middle management positions. They have almost no interest in curriculum at all ... because your curriculum output is not something that measures you as a success [any more]. It's your sort of ability to be able to do administrative tasks, like for example, working a computer, being able to do rolls or to be able to do a timetable. And despite the fact that that's become much easier, because there are programmes and so on, it's given extraordinary credence around here.

Russell, the new Acting Assistant Principal (Operations), had no illusions about how staff generally regarded the 'mundane' daily organizational work:

I'm the Assistant Principal Acting Operations. In other words the timetabler, daily organizer, looking after the things like desks, furniture, and make sure the rooms are right, and the lights are right so the classes can run. There's a lot of the staff that say 'what a load of garbage, you can give that to a cleaner'.

Russell expressed the view that his reward was long overdue, yet there was a sense of apparently mutual resentment between him and a number of teachers who prided themselves on their records of curriculum work. Again, there was the suggestion that 
antagonism between Russell and some other teachers was due as much to older contested positions, in which Russell had been in the minority, as to the current situation. Russell categorizes his opponents as follows:

They won't say it publicly, but they operate out of the assumption that they're doing the working class a favour turning up ... like some sort of precious, self opinionated group who really thought they were 'God's gift'.

In a sense, then, Russell and his opponents were continuing a long-standing debate in which, for Russell, it seemed the wheel had finally turned.

Most teachers we spoke to did not support giving enhanced status to timetabling and other administrative tasks. These skills, to them, were not, and should not be, at the core of teacher professional culture. Yet, they are skills that are important and necessary in any school staff. In the negotiation of professional cultural capital, new priorities were being asserted by which to judge the credibility and validity of the different elements of teachers' work. Unlike in the past, the sanctity of 'curriculum work' in the teacherly repertoire was being challenged by the new centrality of other aspects of the work. Under Schools of the Future policy, the curriculum was becoming more centralized, more regulated, and more focussed on specific outcomes.

Jack defended the 'operations' appointment:

That operations stuff is crucial. That involves furniture, lighting ... it's organized in that sense. A person comes in the morning, they get their extras slips, they know what classes they've got, and there will be 26 chairs and a clean room. You know, all that. Predictable.

A changed view of what constitutes a good teacher seemed to be emerging. One recently appointed teacher (who transferred from a school that had been closed down) put the following view without apparent irony:

Well, I mean, there are things like that you are good at, doing the rolls, and that you do your yard duty meticulously and you don't have to be called, and that you encourage students to pick up papers, and that your classes are quiet. In other words the school runs easily without administrators having to check up on people. That would make you a good teacher.

Rosemary, a teacher who was respected by old radicals like Steve, and who also seemed highly valued by managers, particularly Jack, partly because of her timetabling and other administrative skills, was deeply offended by a change that, to her, crystallized the extent to which the values that underpinned public schooling had changed. This otherwise moderate teacher, and a strong supporter of Jack, said:

I don't think I've been more appalled by anything than the idea that Principals can write off tax for private school fees for their kids ${ }^{4}$... I find that just totally disgusting!

It is difficult to convey on paper the incredulity in Rosemary's voice as she expressed her dismay that Grandridge had become such a 'different' kind of organization in which such a thing was possible. The whole notion that members of the principal class were now employed on special salary packages seemed anathema and helped drive a conceptual wedge between managers and teachers. 
In retrospect, the gap that was opening up between managers and the rest was hardly surprising. There was a strong rhetoric of managerialism in SotF policy, of allowing managers to manage and enabling principals to be 'true leaders' of their schools. Teachers often commented on the contract and salary packaging arrangements, and performance bonuses, of members of the principal class. The gap was by now undermining, at least to some extent, trust between staff and management. The fact that staff and managers at Grandridge once shared a largely common industrial and political perspective made any perceived gap between them now seem even deeper. Indeed, staff attitudes to the administrative team had in some cases become suspicious or even cynical. I have already noted the apparent depth of feeling over the creation of additional assistant principal positions. However, opposition from the school union branch was minimal because, according to one of the leading unionists, '[Jack's] got staff over a barrel'. The union had few bargaining chips against the administration because, as Jack was quick to point out:

I get frustrated sometimes. I have fights with them. You know, 'oh, there'll be flak about this and they might go on strike'. Look, I've got a contract. If they go on strike and upset the enrolments and things, who loses? Not me. I might lose emotionally, but you're going to cost them their jobs by talking down the school and all that sort of stuff.

Any union threat of industrial action could be represented by Jack, and seen by many in the wider school community, not only as putting teachers' jobs in danger but also as a direct and disloyal attack against the school. Teacher loyalty was becoming perceived as loyalty to the individual institution. And the union, even at Grandridge, seemed too weak to assert a wider view of loyalty to 'education' and the 'teaching profession'. As mentioned, in elections for School Council, staff voted for unionists who had been outspoken opponents of the school's entry to the Schools of the Future programme, and who seemed most likely to stand up to management. However, these representatives' inability to constrain the principal in Council had soon been shown up by the vote on the acting assistant principal positions. Gradually, the branch adopted a more conciliatory approach to issues it couldn't win. At the next union elections, staff decided they wanted a conciliator rather than a firebrand or progressive educationalist to lead the branch. The new branch president (a teacher who is affable and not overly critical of the Schools of the Future policy) regretted the growth of disharmony in the school. He directed his efforts towards re-establishing consensus, brokering between the more intransigent and oppositional unionists and the management. As he saw his role: 'Actually my main job [as union president] is to reduce the tension between union members and administrators, and get them to talk together, not at each other'.

Nonetheless, the sense of distance between managers and others that had been explicit in SotF policy had been strongly reinforced in practice by salary packaging, managerial discourse, and the contentious appointment of Russell. Jack had been prepared to go out on a limb to ensure Russell was rewarded. He says he knew the reaction would be hostile but, as he tells the story, this time he was unmovable: 
They didn't like the idea that I could decide ... They got upset and I said that I didn't consult because it would have been a charade. I wanted it. 'I told you what I wanted-I'm having it!'

This was the first time in more than 6 years as principal that Jack dug his heels in and exercised administrative fiat.

\section{Market reputation}

In market terms, Jack not only wanted to ensure that the school's reputation was 'good academically' compared with competitor schools, but he was also seeking points on which Grandridge could be 'unique' or at least 'distinctive'. On occasion, this required a trade-off between educational and market priorities that didn't strictly coincide. For instance, there was the question of how best to use the discretionary funds generated through entrepreneurial activity. In answer to a question about whether he would purchase additional teaching resources, Jack said:

I don't think you'd pay staff. No, I think you'd have lawn tennis courts out here, rather than asphalt ones. Or more grass, you know. But every school's got teachers.

'More grass' could make Grandridge distinctive in a way that having more teachers couldn't. No one we spoke to at Grandridge questioned the underlying assumption that the school needed to compete effectively for its share of enrolments. Indeed, it was interesting to note that, despite the early arguments (discussed above) over whether the 'overarching slogan' for the School Charter would be 'social justice values' or 'a performance orientation', no one who was interviewed approached the question of admissions from a social justice perspective. Instead, even the critics seemed to take on board the managerial, competitive logic. Some, like the radical unionist, Steve, criticized the management for not competing effectively enough. $\mathrm{He}$ accused management of lack of marketing imagination, and came up with his own proposal for how the school could market itself more effectively:

\footnotetext{
Look, what's our comparative advantage over other schools? What is the comparative advantage here? The obvious thing to a parent who really doesn't know the curriculum (everyone's got the widest curriculum in Victoria, blah, blah, blah, blah) is the grounds here. And what's happening is we're getting all that area developed out here, and I said, 'What you do is get a glossy 3 minute video. And you use that as part of the transition programme'.
}

In this comment there is a strong echo of Jack's observation about 'green grass' and the fact that 'every school's got teachers'. Another example of teacher critics adopting the previously somewhat 'foreign' language of managerialism, and, therefore, joining in the shifting of the relative status of professional values, occurred in the wake of the creation of the Assistant Principal (Operations) position. Among the critics of the elevation of 'beancounter' skills was one who argued not so much that the skills were non-core in the profession, but that, in terms of managerial efficiency, developing the timetable should be out-sourced: 'I had suggested that we out-source the timetable anyway ... that we got a private company to do it. We've got a contract 
on our photocopying machine!' Another teacher, although being critical, was also joining in the 'imposed' managerial agenda and arguing that management should be done better:

\begin{abstract}
The problem I see with the administration is that suddenly they've been given these jobs as managers that they've never had before and they don't know how to do it, and they just operate on archaic sorts of paradigms and systems, you know. Jack's still back in the 19th or early 20th century, operating on the old Fordist hierarchical system of organization. Although he says 'yes, yes, we've got to do it differently', all of his actions, moves or whatever, are never any different. It's still the same sort of totally hierarchical approach to things.
\end{abstract}

The perceived centrality of 'bean counters' now, vis a vis the previous professional centrality of 'curriculum people', represented a powerful shift in professional capital and personal identities of many teachers, even though the critical mass of teachers may not have agreed with the shift of legitimacy. This is particularly the case since the teaching staff at Grandridge, almost without exception, were there because they had fought to get positions at the school because its staff had long been regarded as being at the cutting edge of educational thinking and professionalism. Jack, when he got the job as principal at Grandridge, had been grateful to find such curriculum leaders on the staff:

There was a respect for people who were innovative and who tried to improve teaching and learning. They're things that are terrific to inherit ... I think there were very strong elements in the school and they haven't gone away. I think people have come here and added to it.

Teachers like these had come to regard themselves as being among the designers of contemporary education in Victoria. They were people who could claim to have made a difference in the field. However, the agenda asserted by the Kennett government and SotF policy had pulled the rug from under them. They were precisely the kind of educational activists that the government despised for their so-called 'social engineering'. There were many teachers on staff who had been at the forefront of curriculum innovation for a long time, and whose reputations as good practitioners extended outside the school. Some of these teachers, previously recognized as educational leaders, were now complaining that they felt mistrusted and undervalued.

\title{
Discussion
}

Many of the pressures that have been reshaping conceptions of teacher professionalism at Grandridge Secondary College seem to have resulted in professional as well as industrial disempowerment of teachers and to have had ambiguous results. Certainly, prior to the introduction of Schools of the Future policy and its attendant changes, the loyalty of such teachers had been not just to Grandridge but also to a set of educational ideals that many of them believed characterized their profession. Jack acknowledged their idealism and enthusiasm and spirit of innovation, which they associated with their professional orientation, when he arrived at the school. He regarded such 
'professionalism' as his greatest resource in building Grandridge into the school it now is.

In the main, despite scepticism and disappointments about developments during the 1990s, many staff maintained their traditions of educational enthusiasm and still like to see themselves as policy critics. Part of Jack's rationale for entering the Schools of the Future pilot programme was the recognition that these are indeed tough educational times in which Grandridge can use its reputation in order to exert an active influence on the ongoing emergence and reinterpretation of policy. This would be in keeping with the tradition of Grandridge and its educational leaders at various levels being found at the forefront of professional debates and educational policy debates in good times and in bad. Teachers at Grandridge had generally interpreted the policy changes in the 1990s negatively. The responses of many were resistant or defensive, yet, as I have tried to show in this paper, they were complicit in contributing to changes in organizational and professional practice and identities.

Part of being a member of a profession is being able to assert what Bourdieu might call its professional culture or, more precisely in his terms, to define the professional field in terms of its cultural and symbolic capital. Members of the teaching professional field, in other words, define, assert, and defend the body of norms and knowledge that give the profession its internal and external legitimacy. Therefore, although professional knowledge and norms may always be contested from different positions within the profession, the profession's legitimacy rests largely on its sense of its own distinctiveness. Thus, although contested, members are likely to try to keep asserting the status of the broad professional body of knowledge and, if they can't, then the nature and status of the profession becomes more problematic as 'the cultural capital of the [professional] field is lost' (Oakes et al., 1998, p. 263). Teachers at Grandridge would not seem to be at that point yet. However, the professional field is certainly being challenged and shaped in subtle ways. What were previously the main forums for discussion, and often contestation, of educational issues and changes, School Council and Union meetings, are now tame arenas. The core of what was presumed to make 'a good teacher' at Grandridge has been challenged by new parity being given to 'beancounter' skills. The importance of market competition, including the need to attract 'good' students to the school, has been recognized as a pragmatic imperative. This is a strong illustration of the actualization of the 'performance orientation', which, rather than the concept of 'social justice values', had been agreed to as the slogan for the School Charter, initially for pragmatic and defensive reasons. The cultural capital of the professional field, it could be argued, was being problematized. That is, the constituents of what had been regarded at Grandridge as comprising 'a good teacher' (curriculum person, teaching and learning innovation, social justice orientation) would seem to have been being revalued. The previously asserted professional capital, in Bourdieusian terms, was being contested and reconstructed. As Oakes et al. (1998, p. 273) put it:

redefining the [professional] field's dominant capital may not directly affect actors' intrinsic properties [e.g. a teacher's knowledge about and commitment to inclusive curriculum], but it does affect their relational properties (their position), because it affects their overall 
capital, and, therefore, their standing in the field. This, in turn, will have implications for an individual's sense of positional identity.

Importantly, internal critics who had most strongly asserted previous professional values and discourse were also adopting the language of market, managerialism, and other neo-liberal themes of Schools of the Future. The effects on them, as well as on less 'committed' colleagues and on Jack, were experienced not only as the constraints of a coercive policy regime, but also as the institution buying into the policy rhetoric, which defined what was important to talk about. For instance, all sides agreed that there was cultural kudos to be had by the school appearing to be entrepreneurial. Entrepreneurialism and business management, in the new era, endowed some sense of legitimacy on managers, and on the school, in the wider community. The policy emphasis of accountability in direct, accounting terms, like budget reports, shortfalls in achievement of performance targets, and comparative scores in State-wide testing and public examinations, helped make the school directly answerable to an external audience (particularly the informed and 'concerned' citizens who responded positively to the rhetoric of educational crisis, and those aspirational citizens who needed reassurance that the school's academic performance was first rate). Being answerable to your educational peers, your fellow educators, hardly mattered now. Perhaps the most startling illustration of this point was the fact that it was not difficult, in a premier educational institution like Grandridge Secondary College, to decide whether beautifying the already lush grounds or purchasing additional educational resources was more important: there was agreement that more 'green grass' would make the school distinctive and attract students. As Jack said, 'every school's got teachers'. Attracting students, particularly the 'better quality' students from English speaking, middle class backgrounds, became the main thing. This imperative, it could be argued, influenced all other professional judgement.

Particularly important in all this was the relationship between business planning and indicators of success in market terms. As Oakes et al. (1998, p. 280) conclude in relation to museums and cultural heritage sites in Canada that had to react to similar changes and government policies:

Business planning was an act of symbolic violence. Through a process of naming, categorizing, and regularizing, business planning replaced one set of meanings, defined by the producers within the [professional] field, with another set that was defined in reference to the external market. By doing so, this change threatened the relative autonomy of the field and its cultural and symbolic capital. The appearance of business plans as mere acts of technical transcription concealed the force this process involved.

The upshot at the museum was similar to what we observed at Grandridge. Some staff (but by no means all, as I indicated above) who identified strongly with the formerly asserted professional culture, and who saw themselves as 'curriculum' people, 'felt uncomfortable and tended to become less involved as they no longer understood the rules of the game' (Oakes et al., 1998, p. 281). Some of these bailed out and took a severance package. Others, like some of the curators studied by Oakes et al. (1998, p. 281), 'not only embraced the new field but helped give it shape'. Some 
of these, like Russell, who was promoted to Assistant Principal, were clearly winners in the new 'game'.

Within this social world, the dynamics of market and managerialism become transformative devices that conform to the classical logic of 'system-changing' policies and 'policy instruments' (McDonnell \& Elmore, 1987). That is, mechanisms of market and leadership in education can be seen as transformative devices in the implementation of change as much as outcomes in themselves; or, as Ball (1997, p. 327) puts it (when referring to the notion of 'quality' within school effectiveness discourse), such instruments act as 'relay devices' that link 'government "mentalities" and policies with everyday organizational realities'. The discourses that link market, quality, and managerialism 'to the extent that they become regularized into organizational thinking and practices in schools and their communities' have a profound effect on the nature of education and on the nature of the education profession for teachers and managers. It is through analysing such processes and discourses, through which, not by which (Knights \& McCabe, 2000) social relations and identities are constituted, that meanings and norms get challenged and asserted as a result of new articulations of interests and identities (Knights \& McCabe, 2000). Through examining such contextualized micropolitical processes, as I have attempted to do here, we might begin to understand how educational organization and professional identity get accomplished, and we may grasp a sense of the cultural and political mechanisms 'that can be specified and traced' (Dale, 2000), and which lead to the realization of uncertain policy outcomes that may or may not be consistent with the 'forces of globalization'.

The internal re-culturing of schools and education management, in this perspective, is part of the contested contemporary social processes through which broader social and political changes, and the assertion of interests, are imperfectly accomplished. As I have emphasized, the everyday social politics in sites like the school I have described above are connected to, but not determined by, the macro-politics of globalization, the weakening of the nation-state, the fragmentation of civil society, the assertion of alternative social, political and educational norms, the reduction of education to a site of economic planning, the control of schools and teachers by neoliberal governments, and the like. The reconstruction of education as a social institution fits neatly into the neo-liberal cultural agenda, but we are all complicit in such reconstruction in particular sites.

In conclusion, I want to return to my starting criticism that many education writers ascribe recent educational changes to 'forces of globalization' that directly cause increased managerialism, crude accountability measures, and market dominance in education. I have tried to demonstrate, by means of a retrospective analysis of case study data, that 'global' effects, including the effects of policy regimes that strongly reflect neo-liberal values and aspirations, are heavily mediated in context. In doing so, I have been partly influenced by Bacchi (2000), who, in discussing strong discourse theories in writing on globalization that employs a policy-as-discourse perspective, concludes that: 'policy-as-discourse analysts need to spend more time theorizing the "space for challenge"' (Bacchi, 2000, p. 55). She continues: 'I find an overemphasis on the constraints imposed by discourse/s and a tendency to concentrate on some 
groups, those described as "having" power, as the makers and users of discourse'. I agree with Bacchi on this point, but would also argue that, as well as theorizing 'space for challenge', empirical work and explanation is required also of the social action that enables and legitimates discourses, particularly dominant discourses. This point also relates, I think, to a narrow notion of agency that is used in much globalization and education writing. 'Agency' (or the lack of it) is too often presented as the capacity and will (or lack of it) of actors to resist dominant or hegemonic discourses and agendas rather than as the exercise of engagement in discourses and structures in ways that may reinforce as well as challenge them. In other words, we exercise agency when we comply just as much as when we resist. However, the thesis (somewhat tentative) that I have been working on in this paper is that, if we wish to find 'spaces' for resisting and challenging dominant discourses and agendas, we need also to investigate the ways in which we knowingly and unknowingly comply with those discourses and agendas and help accomplish them. Such microanalysis, I argue, must be an essential part of attempts to explain globalization. In the larger report of the Grandridge case study (Angus \& Brown, 1997), we saw many of the aspects discussed above as examples of power plays and resistance at the time, which they were; but in retrospect I see them as having contributed to compliance. That's how attempts at resistance often work. I do not regard this as a negative conclusion or one that suggests the inevitability of compliance. However, I think the case study does illustrate that we need to study how compliance is brought about, and hopefully this may assist us find the spaces for resistance.

\section{Notes}

1. The data collection was conducted jointly with Lynton Brown, whose contribution to the thinking represented in this paper is gratefully acknowledged. This work was funded by a grant from the Australian Research Council.

2. The Liberal Party, founded in Australia by Sir Robert Menzies, has a broad political philosophy that is close to that of the Conservative Party in the UK. The much smaller National Party, once called the Country Party, often joins in coalition with the Liberals to secure government at both State and Commonwealth levels in Australia.

3. The School Council is similar to the English Board of School Governors. Prior to the Kennett government, Council membership of schools in Victoria was balanced between parent and teacher members, but after 1992 the composition was restructured to ensure that there would be a majority of parent members.

4. The reference to tax 'write off' is to a 'salary packaging' scheme for principals that enabled them to arrange for certain expenses (in this case private school fees) to be deducted from their salaries prior to income tax being applied. The accounting can be complicated since 'fringe benefits tax' may be levied, but the idea of the scheme is to deliver a tax advantage. The arrangements were not available to teachers and were seen as contributing to creating a distance between teachers and managers. However, Rosemary's 'disgust' is at the principle of the scheme assisting State school principals to send their own children to private schools.

\section{Notes on Contributor}

Professor Lawrence Angus is Head of the School of Education at the University of Ballarat. His most recent book (with Professor Terri Seddon of Monash 
University) is Beyond nostalgia: reshaping Australian education, published by the Australian Council for Educational Research, Melbourne.

\section{References}

Angus, L. \& Brown, L. (1997) Becoming a school of the future: the micropolitics of policy implementation (Melbourne, Monash University Faculty of Education Publications).

Bacchi, C. (2000) Policy as discourse: what does it mean? Where does it get us?, Discourse, 21(1), $45-57$.

Ball, S. J. (1997) Good schools/bad schools: paradox and fabrication, British fournal of Sociology of Education, 18(3), 317-336.

Beck, J. (1999) Makeover or takeover? The strange death of educational autonomy in neo-liberal England, British Fournal of Sociology of Education, 20(2), 223-238.

Bessant, B. \& Spaull, A. (1976) Politics of schooling (Melbourne, Pitman).

Dale, R. (1999) Specifying global effects on national policy: a focus on the mechanisms, fournal of Education Policy, 14(1), 1-14.

Dale, R. (2000) Globalization and education: demonstrating a 'Common World Educational Culture' or locating a 'Globally Structured Education Agenda'?, Educational Theory, 50(4), 427-448.

Edwards, R., Nicoll, K. \& Tait, A (1999) Migrating metaphors: the globalization of flexibility in policy, Fournal of Education Policy, 14(6), 619-630.

Gaff, J. (1999) An anatomy of educational change: a study of government intervention in the reshaping of education policy in Victoria in the 1990s, unpublished $\mathrm{PhD}$ thesis, Monash University.

Gewirtz, S. \& Ball, S. J. (2000) From 'welfarism' to 'new managerialism': shifting discourses of school headship in the education marketplace, Discourse, 21(3), 253-268.

Hirst, P. \& Thompson, G. (1996) Globalization in question: the international economy and the possibility of governance (Cambridge, Polity Press).

Inglis, F. (2000) A malediction on management, fournal of Education Policy, 15(4), 417-429.

Jones, K. (2001) Travelling policy/local spaces: culture, creativity and interference, paper presented at the Keele conference on 'Travelling policy/local spaces', 27-29 June.

Knights, D. \& McCabe, D. (2000) 'Ain't misbehavin'? Opportunities for resistance under new forms of 'quality' management, Sociology, 34(3), 421-436.

Lawn, M. (2001) Borderless education: imagining a European education space in a time of brands and networks, Discourse, 22(2), 173-184.

McDonnell, L. \& Elmore, R. (1987) Getting the job done: alternative policy instruments, Educational Evaluation and Policy Analysis, 9(2), 133-152.

Morley, L. \& Rassool, N. (2000) School effectiveness: new managerialism, quality and the Japanization of education, fournal of Education Policy, 15(2), 169-183.

Oakes, L., Townley, B. \& Cooper, D. J. (1998) Business planning as pedagogy: language and control in a changing educational field, Administrative Science Quarterly, 48(2), 257-292.

Offe, C. (1996) Designing institutions in East European transitions, in: R. E. Goodin (Ed.) Theory of institutional design (Cambridge, Cambridge University Press), 199-226.

Stryker, R. (1998) Globalization and the welfare state, International fournal of Sociology and Social Policy, 18(2, 3, 4), 1-49.

Victoria: Department of School Education (DSE) (1993) Schools of the Future information kit (Melbourne, DSE).

Whitty, G. (1977) School knowledge and social control (Buckingham, Open University Press).

Whitty, G. (1985) Sociology and school knowledge: curriculum theory, research and politics (London, Methuen).

Wilding, P. (1997) Globalization, regionalism and social policy, Social Policy and Administration, $31(4), 410-428$. 